\title{
The impact of the Pan-African-aged tectonothermal event on high-grade rocks at Mount Brown, East Antarctica
}

\author{
XIAOCHUN LIU ${ }^{10}$, BIN FU ${ }^{2}$, QIULI LI ${ }^{3}$, YUE ZHAO ${ }^{1}$, JIAN LIU1 and HONG CHEN ${ }^{1}$ \\ ${ }^{1}$ Key Laboratory of Paleomagnetism and Tectonic Reconstruction of Ministry of Natural Resources, Institute of Geomechanics, \\ Chinese Academy of Geological Sciences, Beijing 100081, China \\ ${ }^{2}$ Research School of Earth Sciences, The Australian National University, Canberra, ACT 2601, Australia \\ ${ }^{3}$ Institute of Geology and Geophysics, Chinese Academy of Sciences, Beijing 100029, China
}

liuxchqw@cags.ac.cn

\begin{abstract}
This study presents monazite and rutile $\mathrm{U}-\mathrm{Pb}$ and hornblende and biotite ${ }^{40} \mathrm{Ar} /{ }^{39} \mathrm{Ar}$ geochronological data for high-grade rocks of the eastern Grenville-aged Rayner orogen at Mount Brown in order to analyse the extent and degree of Pan-African-aged reworking. Monazite from paragneiss yields $\mathrm{U}-\mathrm{Pb}$ ages of $910 \mathrm{Ma}$ for larger granular grains and 670-630 Ma for smaller globular beads around garnet porphyroblasts or hosted by symplectites. Rutile from leucogneiss yields $\mathrm{U}-\mathrm{Pb}$ ages of 520-515 Ma. Hornblende and biotite from different rock types yield ${ }^{40} \mathrm{Ar} /{ }^{39} \mathrm{Ar}$ plateau ages of 744 and 520-505 Ma, respectively. Combining these results with published zircon U-Pb age data suggests that granulite facies metamorphism occurred at $910 \mathrm{Ma}$, with a local low-temperature fluid flow event at 670-630 Ma and thermal reworking at 520-505 Ma. The older age of 744 Ma may reflect cooling or partial resetting of the hornblende ${ }^{40} \mathrm{Ar} /{ }^{39} \mathrm{Ar}$ system, indicating that Pan-African-aged reworking did not exceed temperatures much higher than the hornblende Ar closure temperature. These data also suggest that the complete isotopic resetting of some minerals may occur without the growth of new mineral phases, providing an example of the style of reworking that is likely to occur in polymetamorphic terranes.
\end{abstract}

Received 2 August 2019, accepted 11 November 2019

Key words: hornblende/biotite ${ }^{40} \mathrm{Ar} /{ }^{39} \mathrm{Ar}$ dating, isotopic resetting, monazite/rutile U-Pb dating

\section{Introduction}

The Rayner orogen, consisting of the Rayner Complex and the Eastern Ghats Belt between the Indian craton (including the Napier Complex in East Antarctica) and the Ruker craton of East Antarctica, is a large Grenville-aged (i.e. late Mesoproterozoic to early Neoproterozoic; $c$. 1000-900 Ma) orogen that extends for $>2000 \mathrm{~km}$ and has a maximum width of $>500 \mathrm{~km}$ (Fig. 1). This orogen was reworked by a Pan-African-aged (i.e. late Neoproterozoic to Cambrian; c. 580-500 Ma) tectonothermal event that varies in intensity from weak reworking in the northern Prince Charles Mountains (Boger et al. 2002, Morrissey et al. 2016) to strong reworking in Prydz Bay (Hensen \& Zhou 1995, Fitzsimons et al. 1997). The main part of the orogen to the east is covered by ice, except for a few isolated outcrops in the vicinity of Mount Brown and the Gaussberg volcano and the Mirny Oasis along the coast of Wilhelm II Land. Some zircons from a mafic granulite and a dioritic vein from the Mirny Oasis and a lamproitic lava of the Gaussberg volcano yield ages of c. $500 \mathrm{Ma}$, suggesting that the coastal part of this area was affected by the Pan-African-aged event (Mikhalsky et al. 2015). However, no new zircon growth or $\mathrm{Pb}$ loss associated with this event has been identified within high-grade rocks from Mount Brown (Mikhalsky et al. 2015, Liu et al. 2016). This led Mikhalsky et al. (2015) to suggest that the Pan-African-aged tectonothermal event became weaker towards inland areas. This study presents the results of combined monazite/rutile $\mathrm{U}-\mathrm{Pb}$ and hornblende/biotite ${ }^{40} \mathrm{Ar} /{ }^{39} \mathrm{Ar}$ dating of metamorphic rocks collected from Mount Brown during the 2014-15 austral field season in order to determine the extent and degree of Pan-African-aged reworking in the eastern part of the Rayner orogen. The new data indicate that the Mount Brown area did indeed undergo Pan-Africanaged reworking, although of relatively low grade, leading to no or partial resetting of the hornblende ${ }^{40} \mathrm{Ar} /{ }^{39} \mathrm{Ar}$ system and the complete resetting of the rutile $\mathrm{U}-\mathrm{Pb}$ and biotite ${ }^{40} \mathrm{Ar} /{ }^{39} \mathrm{Ar}$ isotopic systems, without resulting in the growth of new metamorphic minerals.

\section{Geological background and sampling}

Mount Brown is located between Prydz Bay and the Denman Glacier in East Antarctica and is an elongate 


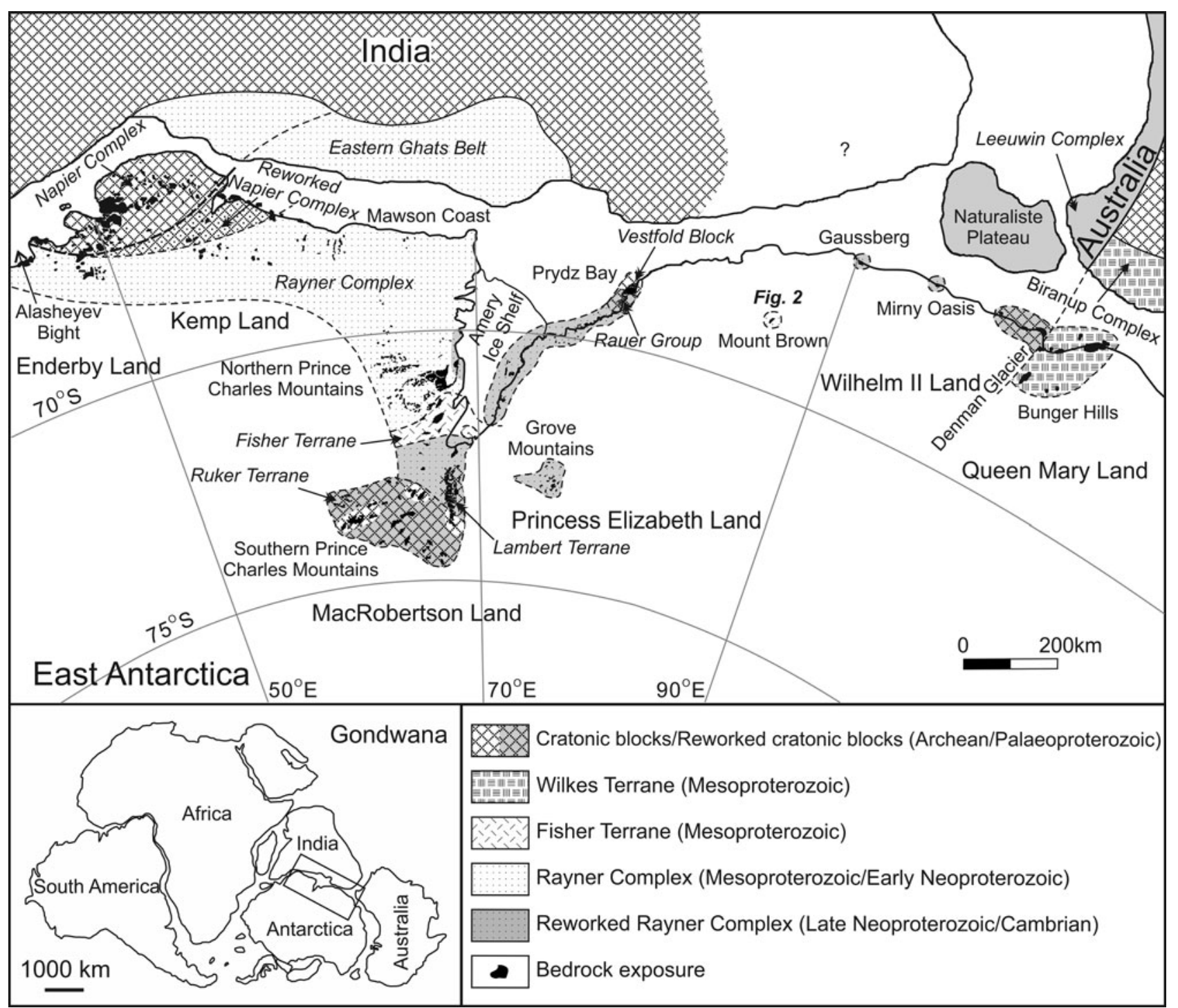

Fig. 1. Geological sketch map of the Indian Ocean sector of Antarctica and adjacent parts of India and Australia prior to the breakup of Gondwana (after Liu et al. 2016). Inset map shows the location of this region within Gondwana at $c$. 500 Ma.

nunatak that protrudes slightly above the continental ice sheet. The outcrop area has a length of $1.5 \mathrm{~km}$ and a width of $50-200 \mathrm{~m}$ (Fig. 2) and is dominated by banded felsic orthogneisses, with subordinate amounts of layered or lenticular mafic granulites, interlayered paragneisses, anatectic leucogneisses and pegmatite veins. Zircon $\mathrm{U}-\mathrm{Pb}$ dating indicates that the protoliths of the mafic granulites and felsic orthogneisses were emplaced at c. 1490-1400 Ma, with deposition of the sedimentary precursors of the paragneisses after c. 1250 Ma. These rocks subsequently underwent high-grade metamorphism and associated partial melting at c. 920-900 Ma (Mikhalsky et al. 2015, Liu et al. 2016). Petrographic textures, mineral compositions and phase equilibria modelling for a mafic granulite and a paragneiss suggest a two-stage evolution for the Grenville-aged metamorphic event, with peak pressure-temperature $(P-T)$ conditions of $830-870^{\circ} \mathrm{C}$ and 7-8 kbar, followed by near-isobaric cooling to 760$830^{\circ} \mathrm{C}$ and $7-8.5 \mathrm{kbar}$ (Liu et al. 2016). The timing and characteristics of these geological events are similar to those recorded within the Rayner Complex in the Prince Charles Mountains-Prydz Bay region (Liu et al. 2013 and references therein).

A total of seven samples from Mount Brown, including four paragneisses, two leucogneisses and one mafic granulite, were used for monazite and rutile $\mathrm{U}-\mathrm{Pb}$ dating and hornblende and biotite ${ }^{40} \mathrm{Ar} /{ }^{39} \mathrm{Ar}$ dating. Paragneiss samples MB03-4, MB04-2, MB04-3 and MB04-6 contain two-stage metamorphic reaction textures defined by a coarse-grained primary (stage I) assemblage of garnet + biotite + plagioclase + quartz + ilmenite \pm orthopyroxene \pm rutile and a fine-grained secondary (stage II) assemblage of garnet + biotite + 


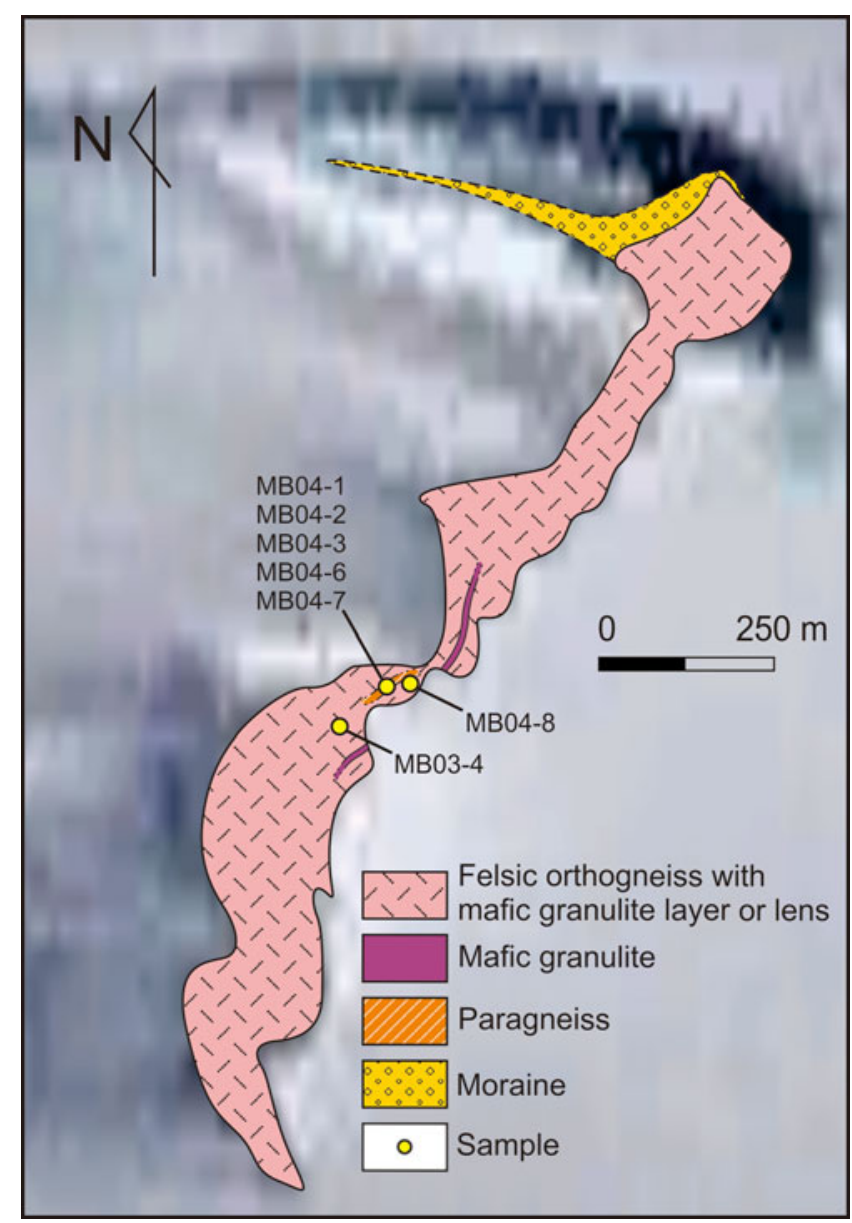

Fig. 2. Geological sketch map of Mount Brown projected on a Google Earth image (modified after Liu et al. 2016).

plagioclase + K-feldspar + quartz + ilmenite \pm hornblende (Fig. 3a \& b). Details of the petrographic characteristics of the paragneiss are given by Liu et al. (2016). Leucogneiss samples MB04-1 and MB04-7 have nearequigranular textures and consist of garnet, biotite, plagioclase, K-feldspar, quartz, rutile and ilmenite. Rutile is intergrown with ilmenite or occurs as individual grains (Fig. 3c). Mafic granulite sample MB04-8 has a coarse-grained primary assemblage of garnet + orthopyroxene + clinopyroxene + hornblende + biotite + plagioclase + quartz + ilmenite + magnetite (Fig. 3d), as well as a locally developed fine-grained secondary assemblage of garnet + clinopyroxene + hornblende + biotite + plagioclase + quartz + ilmenite + magnetite, as described by Liu et al. (2016). The lithologies, mineral assemblages and ages of the studied samples are summarized in Table I.

\section{Analytical techniques}

Monazite $\mathrm{U}-\mathrm{Th}-\mathrm{Pb}$ analyses were performed using a sensitive high-resolution ion microprobe (SHRIMP II) at the Research School of Earth Sciences, Australian National University, Canberra, Australia. Different monazite textural domains were identified on $0.2 \mathrm{~mm}$-thick thin sections that were cut and mounted on epoxy discs along with a primary Thompson Mine monazite standard $(\mathrm{U}=\sim 2100 \mathrm{ppm} ; \quad$ radiogenic $\left.{ }^{206} \mathrm{~Pb} /{ }^{238} \mathrm{U}=0.3152\right)$ and a secondary 44069 standard (424.9 Ma; Aleinikoff et al. 2006). Internal monazite structures were revealed by back-scattered electron (BSE) imaging prior to analysis. Instrumental conditions and data acquisition followed Williams (1998), employing a $10 \mathrm{kV} \mathrm{O}_{2}^{-}$primary ion beam with a current of $\sim 3 \mathrm{nA}$ and a diameter of $\sim 12 \mu \mathrm{m}$. Common $\mathrm{Pb}$ corrections were made using ${ }^{204} \mathrm{~Pb}$ and the resulting data were reduced using the in-house $P R A W N$ and $L E A D$ software (T.R. Ireland). Finally, ages were calculated using the constants recommended by the International Union of Geological Sciences (IUGS) Subcommission on Geochronology and were determined using ISOPLOT. Uncertainties for individual analyses are reported as one standard deviation $(1 \sigma)$ and calculated weighted mean ${ }^{206} \mathrm{~Pb} /{ }^{238} \mathrm{U}$ or ${ }^{207} \mathrm{~Pb} /{ }^{206} \mathrm{~Pb}$ ages are quoted at the $95 \%$ confidence level. The results of these analyses are given in Table SI.

Rutile U-Pb analyses were undertaken by secondary ionization mass spectrometry (SIMS) with a Cameca IMS-1280 large radius instrument at the Institute of Geology and Geophysics, Chinese Academy of Sciences, Beijing, China. Rutile was extracted from samples using conventional crushing, sieving, heavy liquid separation and handpicking techniques. The resulting rutile was mounted in epoxy discs together with rutile standards $\mathrm{R} 10 \quad(\mathrm{U}=\sim 30 \mathrm{ppm}$; concordia age $=1090 \pm 5 \mathrm{Ma}$; Luvizotto et al. 2009), 99JHQ-1 (highly variable U content with an average of $2 \mathrm{ppm} ;{ }^{206} \mathrm{~Pb} /{ }^{238} \mathrm{U}$ age $=$ $218 \pm 1.2 \mathrm{Ma}$; Li et al. 2003) and in-house megacrystic JDX $\left(\mathrm{U}=\sim 6 \mathrm{ppm} ;{ }^{207} \mathrm{~Pb} /{ }^{206} \mathrm{~Pb}\right.$ age $=521 \mathrm{Ma} ;{ }^{206} \mathrm{~Pb} /{ }^{238} \mathrm{U}$ age $=520-500 \mathrm{Ma} ; \mathrm{Li}$ et al. 2011). The mount was then polished to expose the fresh interior of the rutile crystal. Internal rutile structures were determined by BSE imaging before SIMS analysis using the instrument setup and analytical procedures outlined by $\mathrm{Li}$ et al. $(2003,2011)$. This analysis used a primary $\mathrm{O}_{2}^{-}$ion beam accelerated at $13 \mathrm{kV}$, with an intensity of $\sim 15 \mathrm{nA}$. An aperture illumination node (Kohler illumination) was used with a $\sim 200 \mu \mathrm{m}$ aperture to produce even sputtering over the entire area of analysis. The ellipsoidal spot was $\sim 20 \times 30 \mu \mathrm{m}$ in size and positive secondary ions were extracted using a $10 \mathrm{kV}$ potential. The analysis used a mass resolution of $\sim 6000$ and the magnet was cyclically peak-stepped through a sequence including ${ }^{206} \mathrm{~Pb}^{+},{ }^{207} \mathrm{~Pb}^{+},{ }^{208} \mathrm{~Pb}^{+}, \mathrm{U}^{+}, \mathrm{UO}^{+}, \mathrm{ThO}^{+}, \mathrm{UO}_{2}^{+}$ and ${ }^{49} \mathrm{TiO}_{4}^{+}$to produce a single dataset for each analysis. A single ion-counting electron multiplier was used as the detection device and the ${ }^{49} \mathrm{TiO}_{4}^{+}$signal was used as a 

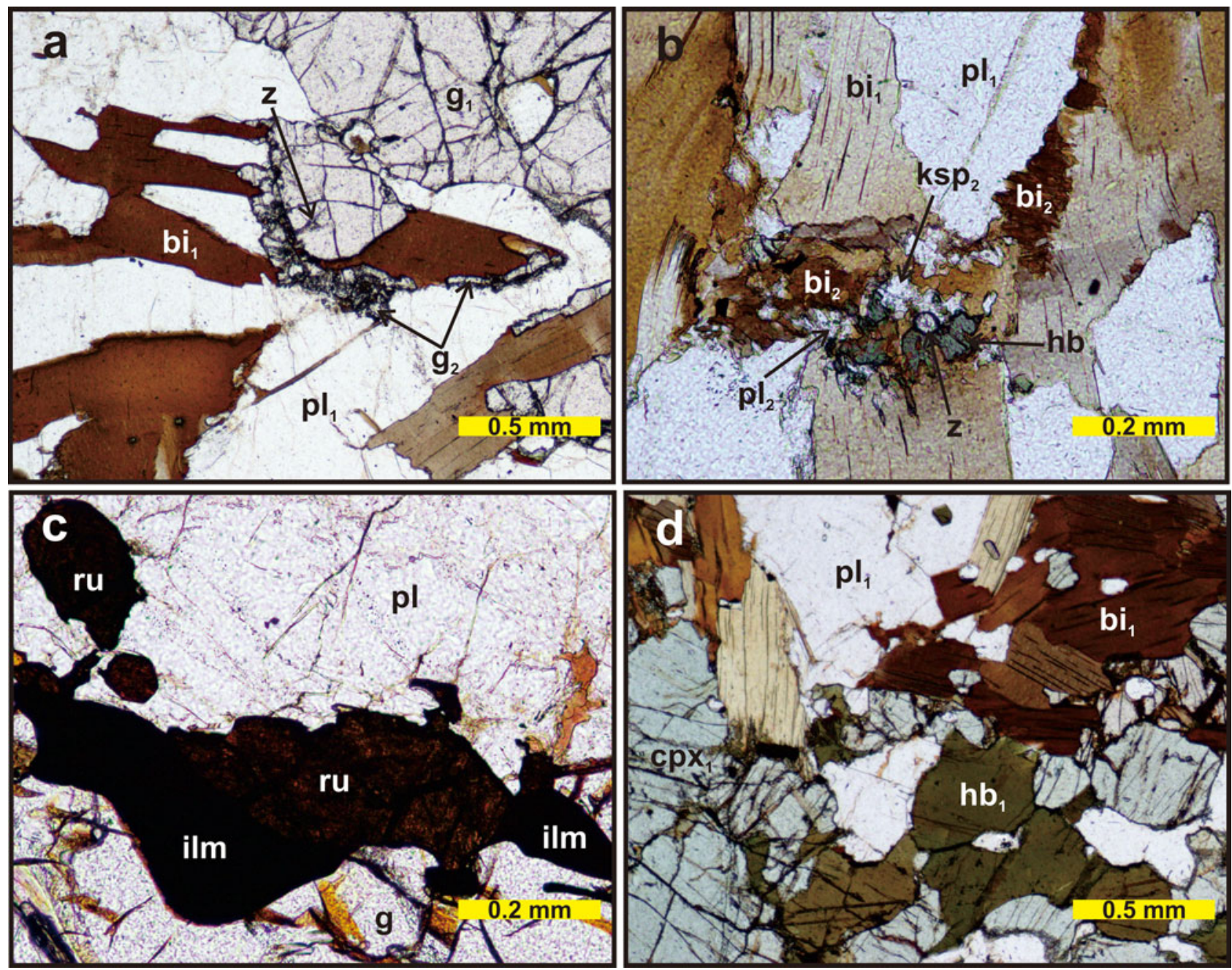

Fig. 3. Plane-polarized light photomicrographs showing mineral textures and paragenesis of paragneiss, leucogneiss and mafic granulite from Mount Brown. a. Primary mineral assemblage of garnet $\left(\mathrm{g}_{1}\right)+$ biotite $\left(\mathrm{bi}_{1}\right)+$ plagioclase $\left(\mathrm{pl}_{1}\right)$ in paragneiss sample MB03-4. Secondary garnet corona $\left(\mathrm{g}_{2}\right)$ developed around primary garnet $\left(\mathrm{g}_{1}\right)$ and biotite $\left(\mathrm{bi}_{1}\right)$. b. Secondary biotite $\left(\mathrm{bi}_{2}\right)$, hornblende $(\mathrm{hb})$, plagioclase $\left(\mathrm{pl}_{2}\right)$ and $\mathrm{K}$-feldspar $\left(\mathrm{ksp}_{2}\right)$ developed between primary biotite $\left(\mathrm{bi}_{1}\right)$ and plagioclase $\left(\mathrm{pl}_{1}\right)$ in paragneiss sample MB03-4. The reaction zone also contains a visible zircon (z) crystal. c. Intergrown rutile (ru) and ilmenite (ilm) in leucogneiss sample MB04-7. d. Primary mineral assemblage of near-equigranular clinopyroxene $\left(\mathrm{cpx}_{1}\right)+\mathrm{hornblende}\left(\mathrm{hb}_{1}\right)+$ biotite $\left(\mathrm{bi}_{1}\right)+$ plagioclase $\left(\mathrm{pl}_{1}\right)$ in sample MB04-8.

Table I. Lithology, mineral assemblages and age results of the studied samples from Mount Brown.

\begin{tabular}{|c|c|c|c|c|c|c|c|c|}
\hline Samples & Lithology & Primary mineral & Secondary mineral & \multicolumn{5}{|c|}{ Age (Ma) } \\
\hline MB03-4 & Paragneiss & $\mathrm{g}, \mathrm{bi}, \mathrm{pl}, \mathrm{q}, \mathrm{ru}, \mathrm{ilm}$ & $\mathrm{g}, \mathrm{hb}, \mathrm{bi}, \mathrm{pl}, \mathrm{ksp}, \mathrm{q}$, ilm & $898 \pm 4$ & & & & $507.65 \pm 1.02$ \\
\hline MB04-3 & Paragneiss & $\mathrm{g}, \mathrm{opx}, \mathrm{bi}, \mathrm{pl}, \mathrm{q}, \mathrm{ilm}$ & $\mathrm{g}, \mathrm{bi}, \mathrm{pl}, \mathrm{ksp}, \mathrm{q}, \mathrm{ilm}$ & $909 \pm 6$ & $909 \pm 8,633 \pm 11$ & & & $505.08 \pm 1.01$ \\
\hline MB04-6 & Paragneiss & $\mathrm{g}, \mathrm{opx}, \mathrm{bi}, \mathrm{pl}, \mathrm{q}, \mathrm{ru}, \mathrm{ilm}$ & $\mathrm{g}, \mathrm{bi}, \mathrm{pl}, \mathrm{ksp}, \mathrm{q}, \mathrm{ilm}$ & & $910 \pm 31,676 \pm 22$ & & & \\
\hline MB04-1 & Leucogneiss & $\mathrm{g}, \mathrm{bi}, \mathrm{pl}, \mathrm{ksp}, \mathrm{q}, \mathrm{ru}, \mathrm{ilm}$ & & & & & & $509.22 \pm 1.03$ \\
\hline
\end{tabular}

$\mathrm{bi}=$ biotite, $\mathrm{cpx}=$ clinopyroxene, $\mathrm{g}=$ garnet, $\mathrm{hb}=$ hornblende, $\mathrm{ilm}=$ ilmenite, $\mathrm{ksp}=\mathrm{K}$-feldspar, $\mathrm{mt}=$ magnetite, opx $=$ orthopyroxene, $\mathrm{pl}=\mathrm{plagioclase}$, $\mathrm{q}=$ quartz, $\mathrm{ru}=$ rutile.

${ }^{a}$ Zircon U-Pb ages are from Liu et al. (2016). 
reference peak for centring of the secondary ion beams because this peak is sufficiently intense and is free of interference from $\mathrm{ZrO}$. Each measurement consisted of 10 cycles and the total analytical time per single analysis was $\sim 15 \mathrm{~min}$. Common $\mathrm{Pb}$ corrections used the ${ }^{207} \mathrm{~Pb}$-based method (Williams 1998, Li et al. 2011). Ages were again calculated using ISOPLOT and age regressions are quoted at the $95 \%$ confidence level. The results of these analyses are given in Table SII.

Hornblende and biotite ${ }^{40} \mathrm{Ar} /{ }^{39} \mathrm{Ar}$ analyses were conducted using a MAP-215/50 mass spectrometer at the College of Earth, Ocean and Atmospheric Sciences, Oregon State University, Corvallis, OR, USA. Hornblende and biotite were extracted using crushing, sieving, heavy liquid separation and handpicking techniques. The samples were then prepared for analysis using the approach outlined by Duncan \& Keller (2004). Separated minerals were placed in evacuated quartz tubes that were wrapped in $\mathrm{Cu}$ foil with unknowns alternating with packages of the FCT-NM sanidine monitor standard $(28.201 \pm 0.023 \mathrm{Ma}$; Kuiper et al. 2008). The resulting $\mathrm{Cu}$ foil-wrapped samples were irradiated for $6 \mathrm{~h}$ in the TRIGA nuclear reactor ICIT facility at Oregon State University. Irradiation parameter $J$ values were estimated using parabolic interpolation, yielding uncertainties of $0.2-0.3 \%$ (Koppers et al. 2000). Interfering $\mathrm{K}$ and $\mathrm{Ca}$ reactions were corrected using the approaches outlined by Koppers et al. (2000). The ${ }^{40} \mathrm{Ar} /{ }^{39} \mathrm{Ar}$ data were obtained using incremental heating, with incremental heating plateau and isochron ages calculated using the $\operatorname{ArArCALC}$ v2.4 software package (Koppers 2002). ${ }^{40} \mathrm{Ar} /{ }^{39} \mathrm{Ar}$ ages are reported with $1 \sigma$ uncertainties, and 46-53 heating steps for each sample were performed to yield plateau ages that are defined by $9-43$ heating steps. The complete experimental data and associated diagrams are given in Table SIII.

\section{Results}

\section{Monazite $\mathrm{U}-\mathrm{Pb}$ dating}

Monazite from paragneiss samples MB04-2, MB04-3 and MB04-6 is present as inclusions in primary minerals such as garnet, biotite, plagioclase and quartz (type I; Fig. 4a \& b), as intergranular crystals in the matrix (type II; Fig. 4c), as individual grains in fine-grained biotite + plagioclase + $\mathrm{K}$-feldspar + quartz + ilmenite \pm garnet symplectites (type III; Fig. 4d-f) and as globular beads either in symplectites or around garnet porphyroblasts (type IV; Fig. $4 \mathrm{~g} \& \mathrm{~h}$ ). The majority of monazite is ovoid, prismatic or irregular and has grain sizes of $20-400 \mu \mathrm{m}$, although the beaded monazite is commonly isometric with grain sizes of $20-40 \mu \mathrm{m}$. Monazite grains are typically zoned in BSE images and have a relatively dark core and a bright rim (Fig. 4a, e \& f). Some grains show reverse zoning patterns (Fig. 4b) and some are homogenous (Fig. 4c). Rare grains in sample MB04-3 have a cloudy-zoned core (Fig. 4d).

A total of 87 SHRIMP spot analyses of 65 monazite grains from three samples yield variable $T h$ and $U$ concentrations that are indistinguishable between cores and $\operatorname{rims}(\mathrm{U}=0.08-0.93 \mathrm{wt} . \%, \mathrm{Th}=0.03-27.26 \mathrm{wt} . \%$ and $\mathrm{Th} / \mathrm{U}=0.19-95.69)$. Twenty-five spot analyses from sample MB04-2 yield ${ }^{206} \mathrm{~Pb} /{ }^{238} \mathrm{U}$ ages ranging from $929 \pm 17$ to $633 \pm 12 \mathrm{Ma}$; of these, 12 older spots (excluding spot $1.1 \mathrm{c}$ with a large uncertainty) on 9 cores and 2 rims of types I and II monazite and 1 core of type III monazite give a weighted mean age of $908 \pm 9 \mathrm{Ma}$ (mean square weighted deviation $[\mathrm{MSWD}]=0.69$ ) (Fig. 5a \& b). The youngest age of $633 \pm 12 \mathrm{Ma}$ is produced by a type IV monazite grain. Seven spot analyses of cloudy-zoned monazite cores from sample MB04-3 yield old ${ }^{207} \mathrm{~Pb} /{ }^{206} \mathrm{~Pb}$ ages varying from $1344 \pm 10$ to $1052 \pm 14 \mathrm{Ma}$. The remaining 41 spots yield ${ }^{206} \mathrm{~Pb} /{ }^{238} \mathrm{U}$ ages between $930 \pm 14$ and $621 \pm 10 \mathrm{Ma}$. Among them, 14 older spots on 6 cores and 1 rim of types I and II monazite and 5 cores and 2 rims of type III monazite give a weighted mean age of $909 \pm 8$ Ma (MSWD $=$ 0.89 ), whereas 4 younger spots on type IV monazite grains produce a weighted mean age of $633 \pm 11 \mathrm{Ma}$ $(\mathrm{MSWD}=0.98)($ Fig. $5 \mathrm{c} \& \mathrm{~d})$. Fourteen spot analyses from sample MB04-6 yield ${ }^{206} \mathrm{~Pb} /{ }^{238} \mathrm{U}$ ages ranging from $958 \pm 17$ to $661 \pm 13 \mathrm{Ma}$; of these, 7 older spots on 5 cores and 1 rim of types I and II monazite and 1 rim of type III monazite give a weighted mean age of $910 \pm 31 \mathrm{Ma}$ $(\mathrm{MSWD}=4.3)($ Fig. 5e \& f). One type IV monazite grain yields a younger age of $676 \pm 22 \mathrm{Ma}$; another analytical spot, which deviated slightly from such a grain, produces an age of $676 \pm 22 \mathrm{Ma}(2.1 \mathrm{c}$; not shown in Fig. 5e).

Statistically, ${ }^{206} \mathrm{~Pb} /{ }^{238} \mathrm{U}$ apparent age trends are shown in Fig. 6 and are summarized as follows: 1) types I and II monazite tend to yield older ages relative to type III monazite, which yields relatively young ages, 2) monazite cores are older than monazite rims barring a grain from sample MB04-6, and 3) all type IV monazite grains, except for a deviated analytical spot from sample MB04-6 (2.1c; not shown in Fig. 6), yield almost the youngest age cluster in each sample.

\section{Rutile $\mathrm{U}-\mathrm{Pb}$ dating}

The dated rutile from sample MB04-1 has grain sizes of $50-150 \mu \mathrm{m}$. A total of 25 SIMS spot analyses of 25 rutile crystals yielded $\mathrm{U}$ concentrations of $0.8-27.0 \mathrm{ppm}$ and common ${ }^{206} \mathrm{~Pb}$ values from $1 \%$ to $72 \%$. Plotting the results of these analyses on a Tera-Wasserburg plot yields a linear regression (excluding four data points with large uncertainties) that defines a lower intercept 

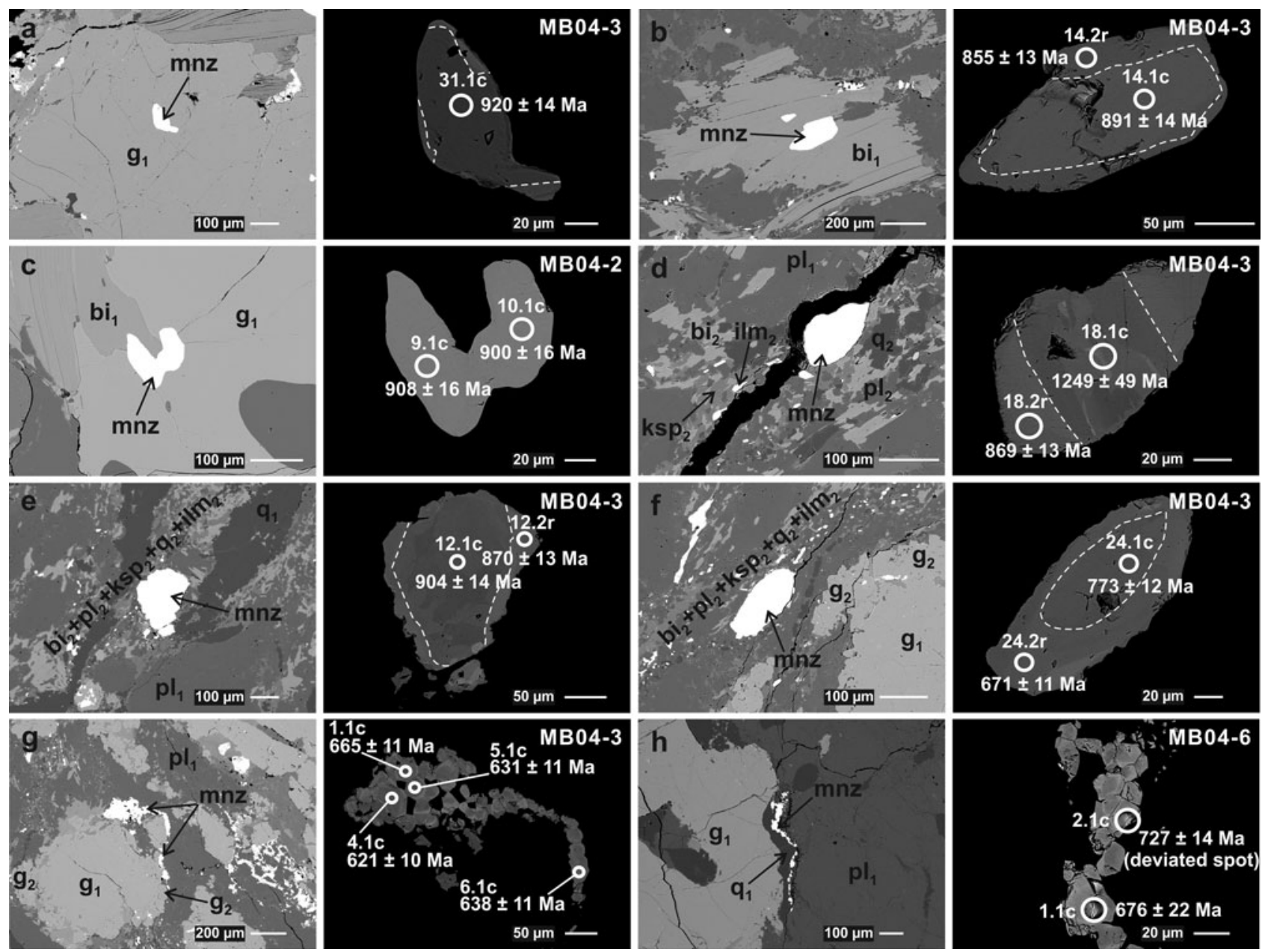

Fig. 4. Representative back-scattered electron images of monazite from paragneisses from Mount Brown. a. Monazite from sample MB04-3 occurring as an inclusion in garnet and showing a dark core and a bright, discontinuous rim. b. Monazite from sample MB04-3 occurring as an inclusion in biotite and showing a bright core and a dark rim. c. Monazite from sample MB04-2 located between garnet and biotite and having a homogeneous structure. d. Monazite from sample MB04-3 hosted by a symplectite and showing a cloudy-zoned core and a bright rim. e. \& f. Monazite from sample MB04-3 hosted by a symplectite and showing a dark core and a bright rim. g. \& h. Monazite from samples MB04-3 and MB04-6 occurring as globular beads around garnet porphyroblast and showing a dark core and a bright rim. Circles with numbers indicate SHRIMP analytical spots with their identification numbers. Ages are given with $1 \sigma$ uncertainties. bi=biotite, $g=$ garnet, ilm $=$ ilmenite, $\mathrm{ksp}=\mathrm{K}-\mathrm{feldspar}$, $\mathrm{mnz}=$ monazite, $\mathrm{pl}=$ plagioclase, $\mathrm{q}=$ quartz.

age of $515 \pm 12 \mathrm{Ma}(n=21, \mathrm{MSWD}=2.0)($ Fig. 7a), which is consistent with the weighted mean ${ }^{206} \mathrm{~Pb} /{ }^{238} \mathrm{U}$ age of $516 \pm 15 \mathrm{Ma}(n=7, \mathrm{MSWD}=1.4)$ obtained for the near-concordant data from this sample (Fig. 7b).

The dated rutile from sample MB04-7 is $200-400 \mu \mathrm{m}$ in diameter. A total of 30 spot analyses of 30 rutile crystals yielded $U$ concentrations of $5.7-160.9 \mathrm{ppm}$ and common ${ }^{206} \mathrm{~Pb}$ values are generally $<10 \%$, although some values lie between $12 \%$ and $76 \%$. A regression of these data points (excluding two outliers) on a TeraWasserburg plot yields a lower intercept age of $520 \pm 8$ Ma $(n=28$, MSWD =1.16) (Fig. 7c), which is within uncertainty of the weighted mean ${ }^{206} \mathrm{~Pb} /{ }^{238} \mathrm{U}$ age of 515 $\pm 10 \mathrm{Ma}(n=17, \quad \mathrm{MSWD}=0.82)$ obtained for the near-concordant data from this sample (Fig. 7d).

\section{Hornblende and biotite ${ }^{40} \mathrm{Ar}{ }^{39}$ Ar dating}

Hornblende and biotite subjected to dating are all coarse-grained crystals that formed during stage I metamorphism. Stage II minerals from mafic granulite (sample MB04-8) and paragneiss (samples MB03-4 and MB04-3) are too fine to be separated. Hornblende from mafic granulite sample MB04-8 yields a plateau age of $743.93 \pm 5.46 \mathrm{Ma}(\mathrm{MSWD}=$ 71.36) defined by $85.59 \%$ of the total ${ }^{39} \mathrm{Ar}$ released (Fig. 8a). In contrast, biotite from mafic granulite (sample MB04-8), paragneiss (samples MB03-4 and MB04-3) and leucogneiss (samples MB04-1 and MB04-7) yields plateau ages ranging from 521.21 \pm $1.19 \mathrm{Ma}(\mathrm{MSWD}=1.38)$ to $505.08 \pm 1.01 \quad \mathrm{Ma}$ 

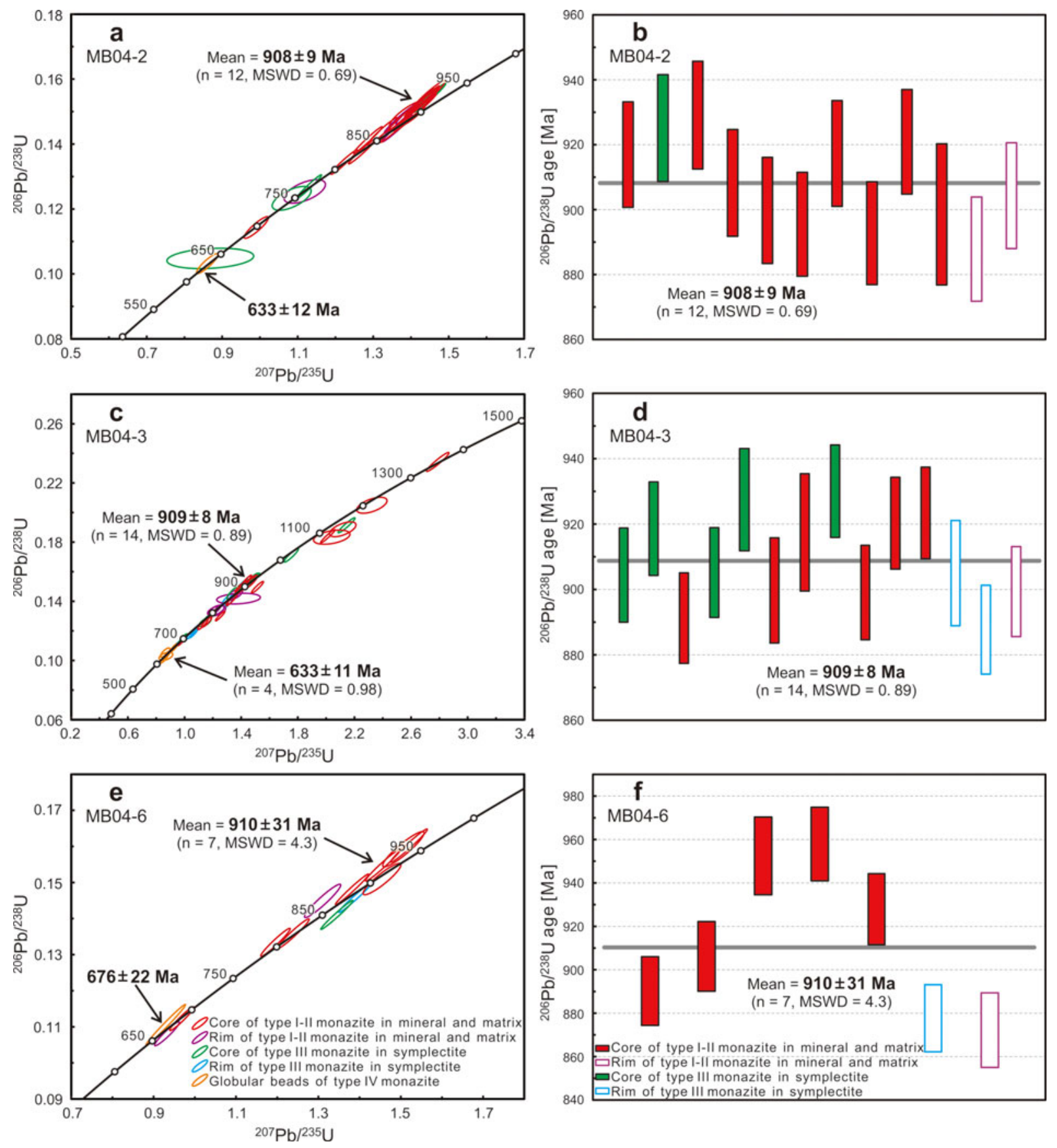

Fig. 5. SHRIMP U-Pb concordia diagrams and distribution plots of ${ }^{206} \mathrm{~Pb} /{ }^{238} \mathrm{U}$ ages for monazite from paragneisses from $\mathrm{Mount}$ Brown. a. \& b. Monazite from sample MB04-2. c. \& d. Monazite from sample MB04-3. e. \& f. Monazite from sample MB04-6.

$(\mathrm{MSWD}=1.30)$ defined by $40.52-99.61 \%$ of the total ${ }^{39} \mathrm{Ar}$ released (Fig. 8b-f).

\section{Discussion}

Interpretation of monazite/rutile $\mathrm{U}-\mathrm{Pb}$ and hornblendelbiotite ${ }^{40} \mathrm{Ar}^{39}$ Ar ages

As the $\mathrm{Pb}$ closure temperature of monazite is thought to be $>900^{\circ} \mathrm{C}$ (Cherniak et al. 2004), this accessory mineral is frequently used to date medium- to high-grade metamorphism. In situ $\mathrm{U}-\mathrm{Pb}$ dating of monazite from three paragneisses from Mount Brown yielded three groups of age data, each of which is geologically significant. Apart from one young age that may have been affected by later $\mathrm{Pb}$ loss, the oldest age group of c. 1340-1180 Ma obtained from cloudy-zoned monazite cores from sample MB04-3 is similar to the detrital zircon ages of $c$. 1500-1250 Ma obtained for the same sample (Liu et al. 2016). However, it is unclear whether 


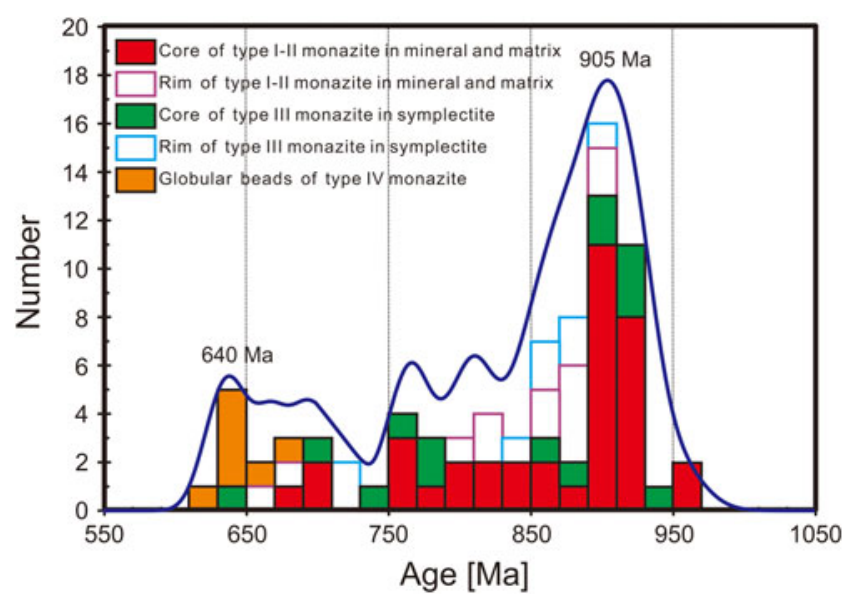

Fig. 6. Cumulative probability histogram showing the distribution of monazite $\mathrm{U}-\mathrm{Pb}$ ages for paragneisses from Mount Brown.

these inherited monazite ages reflect the timing of earlier magmatic, diagenetic or metamorphic events. The major age group of $c .910 \mathrm{Ma}$ determined by the analysis of granular monazite of types I-III is consistent with the ages of c. 920-900 Ma obtained for zircon overgrowth domains in diverse metamorphic rock types in this area (Liu et al. 2016), reflecting the timing of the Grenville-aged high-grade metamorphism. The young age group of $c$. 670-630 Ma was generally obtained from small globular beads of type IV monazite $(<40 \mu \mathrm{m})$ around garnet porphyroblasts or hosted by symplectites. These monazites are thought to have formed as a result of dissolution-reprecipitation processes associated with a low-temperature fluid flow event that did not affect the major mineral assemblages in the rocks (e.g. Harlov et al. 2011, Williams et al. 2011, Kelly et al. 2012). Although type III monazite tends to yield younger ages than types I and II monazite, the fact that some of these monazite grains yield ages $>900 \mathrm{Ma}$ and that their grain sizes are clearly larger than those of syplectitic minerals suggest that these younger ages resulted from the recrystallization of monazite rather than any new growth of it. The cores or rims of some type I monazite grains included in garnet, biotite, plagioclase and quartz
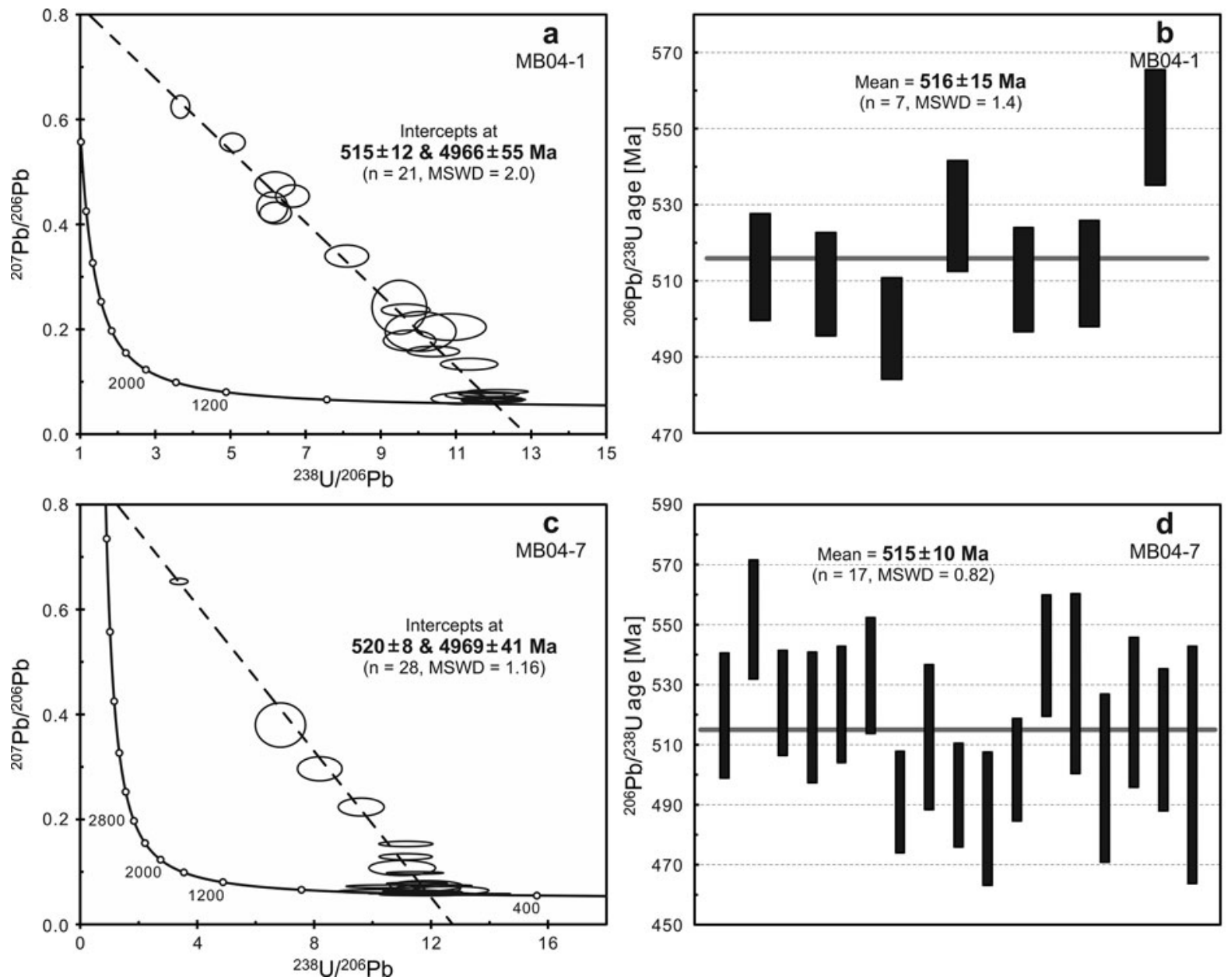

Fig. 7. Secondary ionization mass spectrometry $\mathrm{U}-\mathrm{Pb}$ concordia diagrams and distribution plots of ${ }^{206} \mathrm{~Pb} /{ }^{238} \mathrm{U}$ ages for rutile from leucogneisses from Mount Brown. a. \& b. Rutile from sample MB04-1. c. \& d. Rutile from sample MB04-7. 

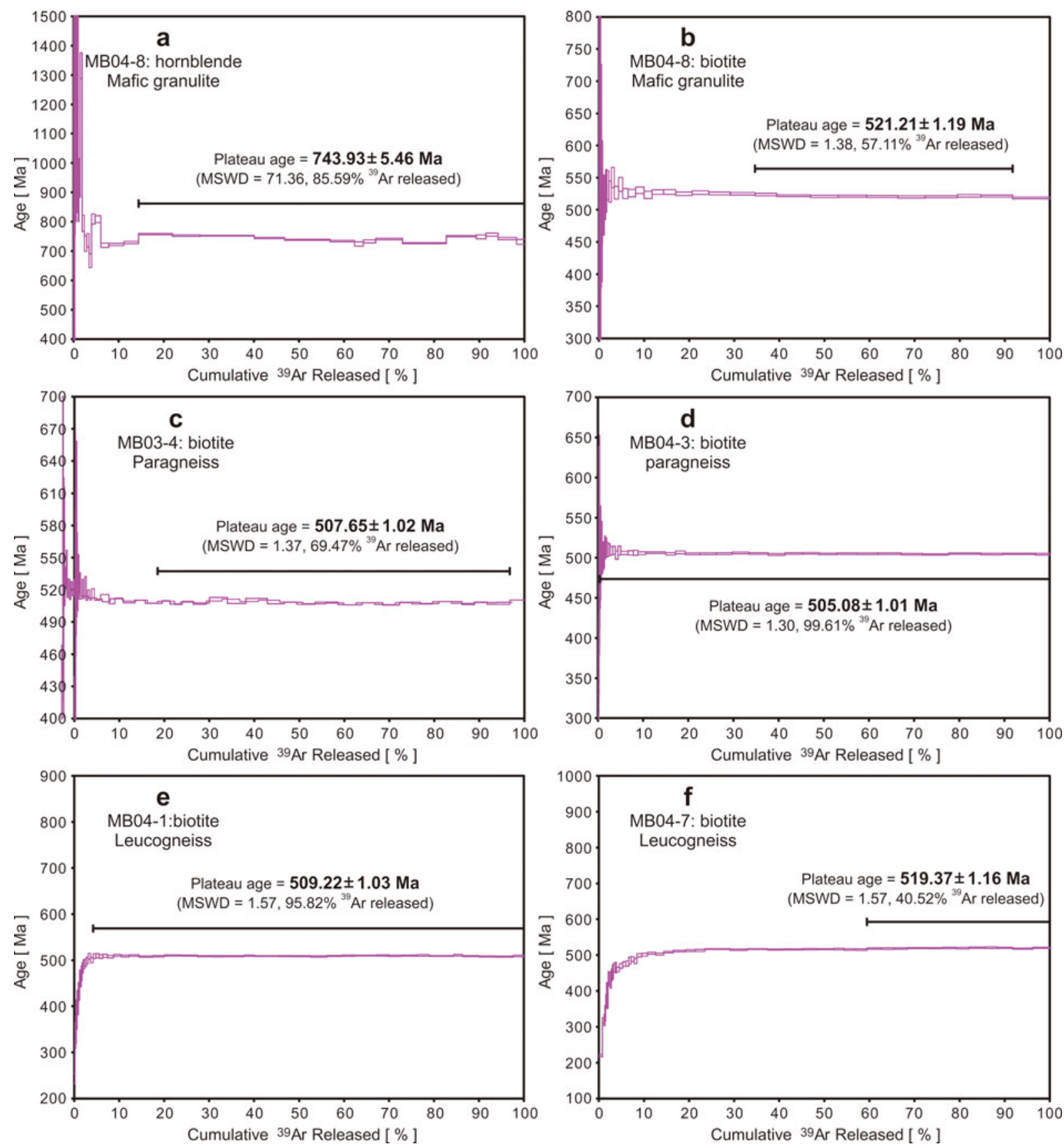

Fig. 8. ${ }^{40} \mathrm{Ar} /{ }^{39} \mathrm{Ar}$ plateau age spectra for hornblende and biotite from different rock types from Mount Brown. a. Hornblende from mafic granulite sample MB04-8. b. Biotite from mafic granulite sample MB04-8. c. Biotite from paragneiss sample MB03-4. d. Biotite from paragneiss sample MB04-3. e. Biotite from leucogneiss sample MB04-1. f. Biotite from leucogneiss sample MB04-7.

also yield relatively young ages (c. 870-760 Ma; see spots $17.1 \mathrm{c}$ and $21.1 \mathrm{c}$ from sample MB04-2 and spots $11.1 \mathrm{c}$, 25.2r and 27.1c from sample MB04-3 in Table SI), further indicating $\mathrm{Pb}$ loss in monazite probably due to slow cooling or the reworking of the Pan-African-aged tectonothermal event. This suggests that any monazite ages between $c .900$ and $c .670$ Ma reflect the timing of isotopic resetting and may have no geological meaning.
The rutile $\mathrm{U}-\mathrm{Pb}$ dating of the two leucogneisses yielded ages of c. $520-515 \mathrm{Ma}$, similar to the biotite ${ }^{40} \mathrm{Ar} /{ }^{39} \mathrm{Ar}$ ages of c. 520-505 Ma obtained from mafic granulite, paragneiss and leucogneiss. However, dating of hornblende from a mafic granulite yielded a ${ }^{40} \mathrm{Ar} /{ }^{39} \mathrm{Ar}$ plateau age of $743.93 \pm 5.46 \mathrm{Ma}$, which is older than the $\mathrm{U}-\mathrm{Pb}$ ages of rutile and the ${ }^{40} \mathrm{Ar} /{ }^{39} \mathrm{Ar}$ plateau ages of biotite. In general, in high-temperature terranes, rutile 


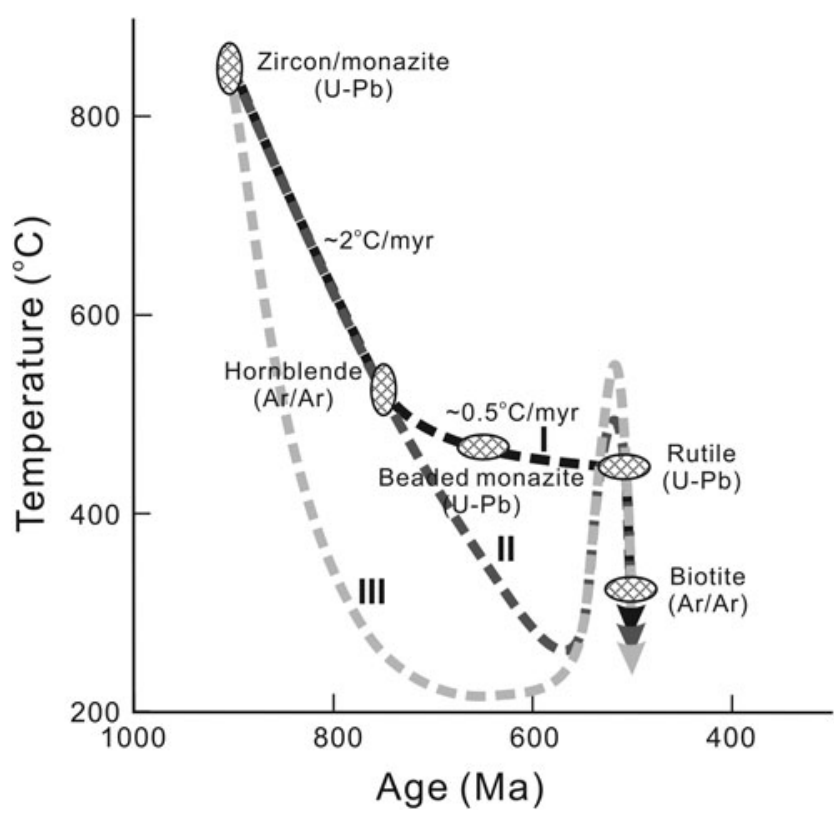

Fig. 9. Possible temperature-time cooling/reheating paths for high-grade rocks from Mount Brown.

$\mathrm{U}-\mathrm{Pb}$ and hornblende/biotite ${ }^{40} \mathrm{Ar} /{ }^{39} \mathrm{Ar}$ ages reflect the timing of cooling of these minerals through the closure temperature $\left(T_{\mathrm{c}}\right)$ of their isotopic systems. The $T_{\mathrm{c}}$ of the ${ }^{40} \mathrm{Ar} /{ }^{39} \mathrm{Ar}$ system is $535 \pm 50^{\circ} \mathrm{C}$ for hornblende and $320 \pm 30^{\circ} \mathrm{C}$ for biotite (McDougall \& Harrison 1999). However, the $T_{\mathrm{c}}$ of the rutile $\mathrm{U}-\mathrm{Pb}$ system remains controversial and appears to be significantly grain size dependent. Although experimental studies on the diffusion of $\mathrm{Pb}$ within rutile suggested a high $T_{\mathrm{c}}$ of $\geq 600^{\circ} \mathrm{C}$ for a grain size of $100 \mu \mathrm{m}$ (Cherniak 2000), numerous field-based studies have demonstrated a relatively low $T_{\mathrm{c}}$ of $450 \pm 50^{\circ} \mathrm{C}$ (Mezger et al. 1989 , Li et al. 2003, 2011, Zack et al. 2011). Our study supports the latter and offers further evidence that the $T_{\mathrm{c}}$ of the rutile $\mathrm{U}-\mathrm{Pb}$ system is lower than that of the hornblende ${ }^{40} \mathrm{Ar} /{ }^{39} \mathrm{Ar}$ system. Given that all of the minerals dated during this study formed during Grenville-aged highgrade metamorphism, there are three possibilities for interpreting the age difference between hornblende, rutile and biotite in the study area. The first is that the Grenville-aged high-grade rocks slowly cooled through $\sim 535^{\circ} \mathrm{C}$ by $744 \mathrm{Ma}$ and then to below $\sim 450^{\circ} \mathrm{C}$ during the period 520-505 Ma, with a cooling rate of $\sim 0.5-2.0^{\circ}$ $\mathrm{C} / \mathrm{myr}$ over c. 400 myr (path I in Fig. 9). Post-tectonic slow cooling with similar rates of $1-3^{\circ} \mathrm{C} / \mathrm{myr}$ has been documented to occur in many deeply eroded high-grade Precambrian orogens (e.g. Willigers et al. 2002). The second is that the rocks underwent a Pan-African-aged reheating event after slow cooling, with a reheating temperature greater than the hornblende Ar closure temperature (path II in Fig. 9). The third is that the Pan-African-aged tectonothermal event reheated the rocks that have rapidly cooled after Grenville-aged high-grade metamorphism (path III in Fig. 9), leading to the partial resetting of the hornblende ${ }^{40} \mathrm{Ar} /{ }^{39} \mathrm{Ar}$ system and the complete resetting of the rutile $\mathrm{U}-\mathrm{Pb}$ and biotite ${ }^{40} \mathrm{Ar} /{ }^{39} \mathrm{Ar}$ systems. We infer that the second or third interpretations are more probable, as the Pan-African-aged tectonothermal event represents an independent orogenic cycle in the Prince Charles Mountains-Prydz Bay region (Liu et al. 2013) and is also likely to have affected the Mount Brown area. The extremely rapid cooling from $\sim 450^{\circ} \mathrm{C}$ to $320^{\circ} \mathrm{C}$ after $520 \mathrm{Ma}$, as indicated by the high similarity of rutile $\mathrm{U}-\mathrm{Pb}$ and biotite ${ }^{40} \mathrm{Ar} /{ }^{39} \mathrm{Ar}$ ages, is discordant with the assumed earlier slow cooling, lending support to these interpretations.

The high-grade metamorphic rocks from Mount Brown record two major stages of mineral growth. Both of the resulting mineral assemblages formed during a single Grenville-aged metamorphic cycle, as evidenced by the fact that some zircon grains located in areas of retrograde reaction textures in paragneisses also yield early Neoproterozoic ages (Liu et al. 2016). The following three lines of evidence support this assumption: 1) the compositions of stage I garnet increase in grossular contents towards garnet rims that have compositions similar to stage II garnet (Liu et al. 2016), indicating that they record a continuous metamorphic process, 2) petrographic observations indicate that the globular beads of monazite with c. 670-630 Ma ages grew after the formation of the coronal and symplectitic minerals, and 3) the new growth of monazite at $c$. 580-500 Ma did not occur in areas with symplectitic textures that formed at higher $P-T$ conditions of $760-830^{\circ} \mathrm{C}$ and $7.0-8.5 \mathrm{kbar}$ (Liu et al. 2016). This demonstrates that no metamorphic reactions occurred in these rocks after the Grenville-aged metamorphic event. In fact, the temperature of the Pan-African-aged tectonothermal event at Mount Brown remains unclear. Although monazite has a high $\mathrm{Pb}$ closure temperature, it can form under greenschist facies conditions $\left(\leq 450^{\circ} \mathrm{C}\right.$; Franz et al. 1996 , Townsend et al. 2000). The small beaded monazite in the samples from the area is also suggestive of relatively lowtemperature hydrothermal activity, as has been documented for similar monazite grains in high-grade metamorphic terranes (e.g. Chen et al. 2012). Considering that the c. 650-600 Ma tectonothermal event has not been recognized in the Rayner Complex, we infer that the hydrothermal fluid flow event that formed the beaded monazite is likely to reflect localized processes. On the other hand, the c. 580-500 Ma tectonothermal event failed to completely reset the hornblende ${ }^{40} \mathrm{Ar} /{ }^{39} \mathrm{Ar}$ system, providing evidence of temperature conditions that were not significantly higher than the hornblende $\mathrm{Ar}$ closure temperature (i.e. $\sim 535^{\circ} \mathrm{C}$ ). 


\section{Implications for the impact of the Pan-African-aged tectonothermal event}

The available data suggest that the Pan-African-aged tectonothermal event affected the vast outcrops in the Prince Charles Mountains-Prydz Bay region (Liu et al. 2013). The recent reports of zircon age records of c. 590-500 Ma in limited outcrops in the Enderby, Wilhelm II and Queen Mary lands indicate that the western and eastern parts of the Rayner Complex were also reworked during the Pan-African-aged event (Mikhalsky et al. 2015, Horie et al. 2016, Daczko et al. 2018, this paper). However, the metamorphic grade of Pan-African-aged reworking varies between different areas or terranes, from granulite facies in the Rayner Complex in Prydz Bay $\left(760-860^{\circ} \mathrm{C}\right.$ and 6-7 kbar; Fitzsimons 1996, Carson et al. 1997) and the northern Prince Charles Mountains $\left(800-870^{\circ} \mathrm{C}\right.$ and $5.5-6.5 \mathrm{kbar}$; Morrissey et al. 2016), to upper amphibolite facies in the Lambert Terrane $\left(650-700^{\circ} \mathrm{C}\right.$ and 6-7 kbar; Boger \& Wilson 2005), lower amphibolite facies in the Ruker Terrane $\left(565-640^{\circ} \mathrm{C}\right.$ and $4-5.2 \mathrm{kbar}$; Phillips et al. 2007) and the Fisher Terrane $\left(550-615^{\circ} \mathrm{C}\right.$ and $2.5-4.0 \mathrm{kbar}$; Van Leeuwen et al. 2019) and greenschist facies in a subglacial Archean block south-east of the Vestfold Hills (chloritoid grade; our unpublished data). Rarer ultrahigh-temperature and high-pressure granulite facies metamorphism has also been identified in the Rauer Group (950-1050 ${ }^{\circ} \mathrm{C}$ and 9.5-12.0 kbar; Harley 1998, Kelsey et al. 2003, Tong \& Wilson 2006) and in the Grove Mountains $\left(770-840^{\circ} \mathrm{C}\right.$ and $11.6-14.0 \mathrm{kbar}$; Liu et al. 2009, Chen et al. 2018), respectively. Therefore, any tectonic model for the Pan-African-aged orogeny in the Indian Ocean sector of Antarctica should incorporate the extent and variability of the metamorphic reworking.

The degree and behaviour of Pan-African-aged reworking also vary spatially within individual areas or terranes. In the case of the Rayner Complex, the most intense metamorphic reworking occurs in the Prydz Bay area and causes penetrative deformation, regional granulite facies metamorphism and widespread partial melting. This leads to the formation of new zircon and monazite in high-grade rocks during the Pan-Africanaged period (e.g. Fitzsimons et al. 1997, Kelsey et al. 2007). In contrast, high-temperature reworking in the northern Prince Charles Mountains only occurs in discrete locations and is characterized by the development of Pan-African-aged monazite-bearing mineral reaction zones without any new zircon growth (Morrissey et al. 2016). Mount Brown provides evidence of another type of thermal reworking that causes the isotopic resetting of some minerals and is not associated with the growth of any new phases. This is similar to the expression of polymetamorphism in the south-western
Vestfold Hills, where mineral-whole-rock Sm-Nd 'isochron' ages for metamorphic rocks range from $670 \pm 7$ to $589 \pm 22 \mathrm{Ma}$, whereas hornblende and biotite ${ }^{40} \mathrm{Ar} /{ }^{39} \mathrm{Ar}$ ages cluster between $526 \pm 4$ and $509 \pm 3 \mathrm{Ma}$ (Liu et al. 2013), and there are no mineral reaction textures associated with the Pan-African ages. In fact, in the absence of penetrative deformation and intensive fluid infiltration, relatively dry granulite facies rocks are rather inert during high-temperature reworking (Morrissey et al. 2016). This means that earlier mineral assemblages are commonly preserved during later metamorphic overprinting, as is the case in numerous polymetamorphic terranes (Morrissey et al. 2016 and references therein). Despite this, some geochronometers with relatively low closure temperatures can still record the timing of such reworking events.

\section{Conclusions}

Almost all of the tectonic units of the Grenville-aged Rayner orogen between the Indian craton (including the Napier Complex in East Antarctica) and the Ruker craton of East Antarctica were affected by the Pan-African-aged tectonothermal event, although varying in metamorphic grade, reworking intensity and mineral growth behaviour. At the eastern part of the Rayner Complex, high-grade metamorphic rocks from Mount Brown only underwent a relatively low-temperature reworking during the Pan-African-aged event, leading to the growth of small monazite beads at $c$. 670-630 Ma, no or partial resetting of the hornblende ${ }^{40} \mathrm{Ar} /{ }^{39} \mathrm{Ar}$ system and the complete resetting of the rutile $\mathrm{U}-\mathrm{Pb}$ and biotite ${ }^{40} \mathrm{Ar} /{ }^{39} \mathrm{Ar}$ isotopic systems at $c$. 520-505 Ma. This suggests that, in the absence of penetrative deformation and intensive fluid infiltration, the complete isotopic resetting of some minerals may occur without the formation of new mineral assemblages in polymetamorphic terranes.

\section{Acknowledgements}

Daniel P. Miggins of Oregon State University kindly performed hornblende and biotite ${ }^{40} \mathrm{Ar} /{ }^{39} \mathrm{Ar}$ analyses. James Hamilton and Yingchun Cui are thanked for their assistance during fieldwork as part of the 2014-15 Chinese National Antarctic Research Expedition. Logistic support from the Australian Antarctic Division and Chinese Arctic and Antarctic Administration is also gratefully acknowledged. Critical reviews by Evgenii Mikhalsky and Laura Morrissey substantially improved the manuscript.

\section{Author contributions}

XL conceived the study and wrote the paper. BF and QL performed the monazite and rutile $\mathrm{U}-\mathrm{Pb}$ analyses, 
respectively. JL and $\mathrm{HC}$ assisted in field sampling. YZ commented on the manuscript.

\section{Financial support}

This research was supported by the National Natural Science Foundation of China (No. 41530209), Central Public-Interest Scientific Institution Basal Research Fund (No. JYYWF201819) and Geological Investigation Project of the Chinese Geological Survey (No. DD20190579).

\section{Supplemental material}

Supplemental tables and figures will be found at https:// doi.org/10.1017/S0954102019000518.

\section{References}

Aleinikoff, J.N., Schenck, W.S., Plank, M.O., Srogi, L.-A., Fanning, C.M., Kamo, S.L. \& Bosbyshell, H. 2006. Deciphering igneous and metamorphic events in high-grade rocks of the Wilmington Complex, Delaware: morphology, cathodoluminescence and backscattered electron zoning, and SHRIMP U-Pb geochronology of zircon and monazite. Geological Society of American Bulletin, 118, 39-64.

Boger, S.D. \& WiLSON, C.J.L. 2005. Early Cambrian crustal shortening and a clockwise $P-T-t$ path from the southern Prince Charles Mountains, East Antarctica: implications for the formation of Gondwana. Journal of Metamorphic Geology, 23, 603-623.

Boger, S.D., Carson, C.J., Fanning, C.M., Hergt, J.M., Wilson, C.J.L. \& Woodhead, J.D. 2002. Pan-African intraplate deformation in the northern Prince Charles Mountains, East Antarctica. Earth and Planetary Science Letters, 195, 195-210.

Carson, C.J., Powell, P., Wilson, C.J.L. \& Dirks, P.H.G.M. 1997. Partial melting during tectonic exhumation of a granulite terrane: an example from the Larsemann Hills, East Antarctica. Journal of Metamorphic Geology, 15, 105-126.

Chen, C.-H., Liu, Y.-H., Lee, C.-Y., Xiang, H. \& Zhou, H.-W. 2012. Geochronology of granulite, charnockite and gneiss in the poly-metamorphosed Gaozhou Complex (Yunkai massif), South China: emphasis on the in-situ EMP monazite dating. Lithos, 144145, 109-129.

Chen, L.Y., WANG, W., Liu, X.C. \& ZhaO, Y. 2018. Metamorphism and zircon $\mathrm{U}-\mathrm{Pb}$ dating of high-pressure pelitic granulites from glacial moraines in the Grove Mountains, East Antarctica. Advances in Polar Science, 29, 118-134.

Cherniak, D.J. 2000. Pb diffusion in rutile. Contribution to Mineralogy and Petrology, 139, 198-207.

Cherniak, D.J., Watson, E.B., Grove, M. \& Harrison, T.M. 2004. Pb diffusion in monazite: a combined RBS/SIMS study. Geochimica et Cosmochimica Acta, 68, 829-840.

Daczko, N., Halpin, J.A., Fitzsimong, I.C.W. \& Whittaker, J.M. 2018. A cryptic Gondwana-forming orogen located in Antarctica. Scientific Reports, 8, 8371.

Duncan, R.A. \& Keller, R.A. 2004. Radiometric ages for basement rocks from the Emperor Seamounts, ODP Leg 197. Geochemistry, Geophysics, Geosystems, 5, 10.1029/2004GC000704.

Fitzsimons, I.C.W. 1996. Metapelitic migmatites from Brattstrand Bluffs, East Antarctica-metamorphism, melting and exhumation of the mid crust. Journal of Petrology, 37, 395-414.
Fitzsimons, I.C.W., Kinny, P.D. \& Harley, S.L. 1997. Two stages of zircon and monazite growth in anatectic leucogneiss: SHRIMP constraints on the duration and intensity of Pan-African metamorphism in Prydz Bay, East Antarctica. Terra Nova, 9, 47-51.

Franz, G., Andrehs, G. \& Rhede, D. 1996. Crystal chemistry of monazite and xenotime from Saxothuringian-Moldanubian metapelites, NE Bavaria, Germany. European Journal of Mineralogy, 8, 1097-1118.

HARLEY, S.L. 1998. Ultrahigh temperature granulite metamorphism $\left(1,050^{\circ} \mathrm{C}, 12 \mathrm{kbar}\right)$ and decompression in garnet $(\mathrm{Mg} 70)$ orthopyroxene-sillimanite gneisses from the Rauer Group, East Antarctica. Journal of Metamorphic Geology, 16, 541-562.

Harlov, D.E., Wirth, R. \& Hetherington, C.J. 2011. Fluid-mediated partial alteration in monazite: the role of coupled dissolutionreprecipitation in element redistribution and mass transfer. Contributions to Mineralogy and Petrology, 162, 329-348.

Hensen, B.J. \& Zhou, B. 1995. A Pan-African granulite facies metamorphic episode in Prydz Bay, Antarctica: evidence from Sm-Nd garnet dating. Australian Journal of Earth Sciences, 42, 249-258.

Horie, K., Hokada, T., Motoyoshi, Y., Shiraishi, K., Hiroi, Y. \& TAKEHARA, M. 2016. U-Pb zircon geochronology in the western part of the Rayner Complex, East Antarctica. Journal of Mineralogical and Petrological Sciences, 111, 104-117.

Kelly, N.M., Harley, S.M. \& Möller, A. 2012. Complexity in the behavior and recrystallization of monazite during high- $T$ metamorphism and fluid infiltration. Chemical Geology, 322-323, 192-208.

Kelsey, D.E., White, R.W., Powell, R., Wilson, C.J.L. \& Quinn, C.D. 2003. New constraints on metamorphism in the Rauer Group, Prydz Bay, East Antarctica. Journal of Metamorphic Geology, 21, 739-759.

Kelsey, D.E., Hand, M., Clark, C. \& Wilson, C.J.L. 2007. On the application of in situ monazite chemical geochronology to constraining $P-T-t$ histories in high-temperature $\left(>850^{\circ} \mathrm{C}\right)$ polymetamorphic granulites from Prydz Bay, East Antarctica. Journal of Geological Society London, 164, 667-683.

Koppers, A.A.P. 2002. $\operatorname{ArArCALC}$ - software for ${ }^{40} \mathrm{Ar} /{ }^{39} \mathrm{Ar}$ age calculations. Computers \& Geosciences, 28, 605-619.

Koppers, A.A.P., Staudigel, H. \& Wijbrans, J.R. 2000. Dating crystalline groundmass separates of altered Cretaceous seamount basalts by the ${ }^{40} \mathrm{Ar} /{ }^{39} \mathrm{Ar}$ incremental heating technique. Chemical Geology, 166, 139-158.

Kuiper, K.F., Deino, A., Hilgen, F.J., Krijgsman, W., Renne, P.R. \& WiJBRANSET, J.R. 2008. Synchronizing rock clocks of Earth history. Science, 320, 500-504.

Li, Q.L., Li, S.G., Zheng, Y.-F., Li, H.M., Massonne, H.J. \& WANG, Q.C. 2003. A high precision $\mathrm{U}-\mathrm{Pb}$ age of metamorphic rutile in coesite-bearing eclogite from the Dabie Mountains in central China: a new constraint on the cooling history. Chemical Geology, 200, 255-265.

LI, Q.L., LIN, W., Su, W., Li, X.H., ShI, Y.H., LiU, Y. \& TANG, G.Q. 2011. SIMS $\mathrm{U}-\mathrm{Pb}$ rutile age of low-temperature eclogites from south-western Chinese Tianshan, NW China. Lithos, 122, 76-86.

Liv, X.C., Hu, J., Zhao, Y., Lou, Y., Wei, C. \& Liv, X.H. 2009. Late Neoproterozoic/Cambrian high-pressure mafic granulites from the Grove Mountains, East Antarctica: $P-T-t$ path, collisional orogeny and implications for assembly of East Gondwana. Precambrian Research, 174, 181-199.

Liv, X.C., Zhaо, Y. \& Hu, J.M. 2013. The c. 1000-900 Ma and c. 550-500 Ma tectonothermal events in the Prince Charles Mountains-Prydz Bay region, East Antarctica, and their relations to supercontinent evolution. In Harley, S.L., Fitzsimons, I.C.W. \& Zhao, Y., eds. Antarctica and supercontinent evolution. Special Publication of the Geological Society of London, No. 283, 95-112.

Liv, X.C., Wang, W.R.Z., Zhao, Y., Liu, J., Chen, H., Cui, Y.C. \& Song, B. 2016. Early Mesoproterozoic arc magmatism followed by early Neoproterozoic granulite facies metamorphism with a near-isobaric 
cooling path at Mount Brown, Princess Elizabeth Land, East Antarctica. Precambrian Research, 284, 30-48.

Luvizotto, G.L., Zack, T., Meyer, M.P., Ludwig, T., Triebold, S., Kronz, A., et al. 2009. Rutile crystals as potential trace element and isotope mineral standards for microanalysis. Chemical Geology, 261, 346-369.

McDougall, I. \& Harrison, T.M. 1999. Geochronology and thermochronology by the ${ }^{40} \mathrm{Ar} / \mathrm{P}^{39} \mathrm{Ar}$ method, 2nd ed. Oxford: Oxford University Press, $269 \mathrm{pp}$.

Mezger, K., Hanson, G.N. \& Bohlen, S.R. 1989. High-precision U-Pb ages of metamorphic rutile: application to the cooling history of high-grade terranes. Earth and Planetary Science Letters, 96, 106-118.

Mikhalsky, E.V., Belyatsky, B.V., Presnyakov, S.L., Skublov, S.G., Kovach, V.P., Rodionov, N.V., et al. 2015. The geological composition of the hidden Wilhelm II Land in East Antarctica: SHRIMP zircon, $\mathrm{Nd}$ isotopic and geochemical studies with implications for Proterozoic supercontinent reconstructions. Precambrian Research, 258, 171-185.

Morrissey, L.J., Hand, M., Kelsey, D.E. \& Wade, B.P. 2016. Cambrian high-temperature reworking of the Rayner-Eastern Ghats Terrane: constraints from the northern Prince Charles Mountains region, East Antarctica. Journal of Petrology, 57, 53-92.

Phillips, G., White, R.W. \& Wilson, C.J.L. 2007. On the role of deformation and fluid during rejuvenation of a polymetamorphic terrane: inferences on the geodynamic evolution of the Ruker
Province, East Antarctica. Journal of Metamorphic Geology, 25, 855-871.

Tong, L. \& Wilson, C.J.L. 2006. Tectonothermal evolution of the ultrahigh temperature metapelites in the Rauer Group, East Antarctica. Precambrian Research, 149, 1-20.

Townsend, K.J., Miller, C.F., D’Andrea, J.L., Ayers, J.C., Harrison, T.M. \& CоAтH, C.D. 2000. Low temperature replacement of monazite in the Ireteba Granite, southern Nevada; geochronological implications. Chemical Geology, 172, 95-112.

Van Leeuwen, A.T.D.V., Morrissey, L.J., Kelsey, D.E. \& Raimondo, T. 2019. Recognition of Pan-African-aged metamorphism in the Fisher Terrane, central Prince Charles Mountains, East Antarctica. Journal of the Geological Society, 28, 10.1144/jgs2018-146.

Williams, I.S. 1998. U-Th-Pb geochronology by ion microprobe. Reviews in Economic Geology, 7, 1-35.

Williams, M.L., Jercinovic, M.J., Harlov, D.E., Budzyn, B. \& Hetherington, C.J. 2011. Resetting monazite ages during fluidrelated alteration. Chemical Geology, 283, 218-225.

Willigers, B.J.A., Van Gool, J.A.M., Wijbrans, J.R., Krogstad, E.J. \& Mezger, K. 2002. Posttectonic cooling of the Nagssugtoqidian orogen and a comparison of contrasting cooling histories in Precambrian and Phanerozoic orogens. Journal of Geology, 110, 503-517.

Zack, T., Stockli, D.F., Luvizotto, G.L., Barth, M.G., Belousova, E., Wolfe, M. \& Hinton, R.W. 2011. In situ U-Pb rutile dating by LA-ICP-MS: ${ }^{208} \mathrm{~Pb}$ correction and prospects for geological applications. Contributions to Mineralogy and Petrology, 162, 515-530. 